\title{
Jak działają rzeczy społeczne. Poznanie, normatywność i dizajn dla mas
}

\author{
Witold Wachowski \\ Instytut Filozofii, Uniwersytet Warszawski \\ Instytut Filozofii i Socjologii PAN \\ witoldwachowski@gmail.com
}

Przyjęto: 1 września 2017; zaakceptowano: 20 listopada 2017

\begin{abstract}
Abstrakt
O społecznym uwikłaniu rzeczy można mówić nie tylko językiem posthumanizmu. Ludzie projektują i wytwarzają artefakty. Społeczny charakter tym ostatnim nadaje nie tylko wykorzystanie powszechne czy we współpracy między ludźmi, lecz również system różnorodnych norm społecznych, w ramach którego korzystamy z tych rzeczy, co zarysowuję we wprowadzeniu. Wątek usytuowania artefaktów społecznych w praktykach normatywnych podejmuję z perspektywy ekologii poznawczej i jednocześnie teorii dizajnu, korzystających $\mathrm{z}$ koncepcji afordancji; przedstawiam to $\mathrm{w}$ trzech kolejnych częściach pracy. Trzecia $\mathrm{z}$ nich zawiera też wstępne omówienie roli standaryzacji rzeczy masowo produkowanych lub wykorzystywanych przez duże grupy ludzi. W następnej części próbuję zidentyfikować zakres uwikłania rzeczy w realizację codziennych praktyk normatywnych; zwracam przy tym uwagę nie tylko na afordancje, lecz i na rolę emocji, rozciągam też zakres rozważań na obiekty użytku publicznego oraz wskazuję na rolę innych ludzi.
\end{abstract}

Słowa kluczowe: ekologia poznawcza; artefakt; norma społeczna; afordancja; dizajn 
$Z$ designem jak z policja.

Nigdy go nie ma tam, gdzie jest najbardziej potrzebny.

(Marcin Wicha, 2015)

\section{Wprowadzenie}

Wątki społeczne w naukach poznawczych traktowane są na różny sposób: od ostrożnościowego podejścia neuronauki (Schutt i in., 2015) do brawurowej koncepcji rozproszonego systemu poznawczego, w którym ludzie są komponentami, i to obok artefaktów (Hutchins, 2014). Moja propozycja dotyczy jedynie pewnego wycinka tej problematyki, mniej popularnego, przy czym w niniejszym studium kieruję ją do możliwie szerokiej grupy czytelników. Fenomenem społecznego uwikłania rzeczy zajmowano się już nieraz w obrębie samych nauk społecznych, że wspomnę tylko o frapujących dociekaniach z zakresu teorii aktora-sieci (ANT). Jest to jednocześnie fenomen poznawczy. Dlatego podejmuję ten wątek $\mathrm{z}$ perspektywy badań nad poznaniem, aby wstępnie pokazać, do jakiego stopnia mogą się one tutaj obyć bez bezpośrednich odwołań do nauk społecznych. Nie będę odnosił się do analogicznych wątków w ANT czy ogólnie w nurcie posthumanizmu również z uwagi na pewną rozbieżność podstawowych założeń i celów badawczych. Także z powodu względnie skromnej objętości tekstu ${ }^{1}$ decyduję się nie mówić o tym, czego nie obejmuje zakres mojej pracy - a więc nie tworzyć porównań z badaniami społecznymi ani nie kreślić wizji potencjalnej współpracy. Są to rozległe tematy na oddzielne rozprawy.

Pojęcia rzeczy społecznych, dotyczącego społecznego uwikłania rzeczy, używam tutaj w zawężonym zakresie, inaczej trudno byłoby wskazać taką rzecz, której to uwikłanie jest obce. Bycie przedmiotem społecznym uważam za stopniowalne oraz wielowymiarowe. Stopniowalność dotyczy popularności, dostępności i częstotliwości używania jakiegoś przedmiotu w danej społeczności. W tym sensie rzeczy codziennego użytku (krzesła, telefony) są bardziej społeczne niż te, których nie zdążyła bardziej objąć ludzka rutyna (jak dzieła sztuki czy sprzęt medyczny ułatwiający życie bardziej poszkodowanym pacjentom). Natomiast do wymiarów „bycia rzeczą społeczną” należy powszechność użycia rzeczy (takich jak wyposażenie łazienek), przydatność we współpracy, zbiorowych sportach czy zbiorowej rozrywce (narzędzia, akcesoria sportowe lub do gier), ale i w zarządzaniu funkcjonowaniem większych grup czy wręcz tłumu (wyposażenie miejsc pracy, obiekty użyteczności publicznej), wykorzystanie w komunikacji międzyludzkiej (komputery z podłączeniem internetowym, wspomniane już telefony i obiekty użyteczności publicznej).

\footnotetext{
${ }^{1} \mathrm{~W}$ artykule rozwijam wybrane wątki zasygnalizowane przeze mnie we współautorskiej pracy: Michał Piekarski i Witold Wachowski, Artefacts as Social Things: Design-Based Approach to Normativity (w przygotowaniu).
} 
Kolejnym wymiarem jest bycie środkiem masowej komunikacji (gazeta, telewizor, billboard). Pamiętajmy przy tym, że rzeczy mogą również nabyć nietypowej czy nieprzewidzianej dla nich roli społecznej (jak mury wykorzystywane pod graffiti czy praktycznie każdy przedmiot domowy lub obiekt publiczny, który okazuje się przydatny dla protestującej czy zbuntowanej grupy ludzi). Wreszcie do wymiarów bycia społecznym należy również organizacja sposobu wytwarzania i dystrybucji wielu artefaktów, popularyzowanie ich w mediach, kontrola sposobu użycia oraz wszystko to, co wiąże się z masową produkcją przemysłową i standaryzacją jej wytworów.

I ten wymiar interesuje mnie tutaj najbardziej. Posiadające go rzeczy to artefakty wytwarzane dla mas lub służące do obsługi mas, a więc dystrybuowane w handlu lub wykorzystywane w usługach. Ich powszechność, standaryzacja i kontrolowalność mogą się wydawać nazbyt oczywistymi wyznacznikami bycia społecznym, czyli (w tym przypadku) bycia dla społeczności i w społeczności; niemniej będę się starał pokazać, że nie są one przykładem trywialnym.

Z wszystkimi przywołanymi wymiarami i reprezentującymi je rzeczami wiąże się zagadnienie normatywności. Używanie rzeczy jest niejako „przesycone” normami społecznymi różnego rodzaju. W niniejszym studium zagadnienie rzeczy społecznych osadzam w ekologii poznawczej oraz częściowo w teoriach dizajnu². Skoncentruję się na materialnym wymiarze praktyk normatywnych związanych z wykorzystaniem rzeczy społecznych, tym samym abstrahując, jak już wspomniałem, od ustaleń nauk społecznych.

Zanim przejdę do dyskusji nad społecznym statusem artefaktów, wyjaśnię pojęcie ekologii poznawczej oraz norm społecznych. Ekologia poznawcza bada zjawiska poznawcze w ich kontekście. Dlatego przedmiotem jej badań stają się kulturowe ekosystemy poznawcze, w których skład wchodzą obiekty fizyczne, modele umysłowe oraz praktyki kulturowe. Edwin Hutchins - teoretyk dość uniwersalnej koncepcji badania poznania jako procesów rozproszonych wskazuje na trzy historyczne ujęcia ważne dla ekologii poznawczej: kulturowohistoryczną teorię działania Lwa Wygotskiego, Batesonowską ekologię umysłu oraz psychologię ekologiczną Jamesa Gibsona (Hutchins, 2010, s. 705-709). Zdaniem Hutchinsa ludzkie procesy myślowe to rodzaj praktyki kulturowej, której uczymy się w toku ucieleśnionych interakcji, zgodnie z procesami społeczno-materialnymi i obecnymi w świecie znaczeniami. Jest to nauka nie przez obserwację, lecz przez współuczestniczenie (Hutchins, 1995, s. 353-355; 2014, s. 34-49).

\footnotetext{
${ }^{2}$ Posługuję się tutaj określeniem „dizajn”, ponieważ jego rozumienie wykracza poza synonim projektowania i wzornictwa, gdyż dotyczy zarówno czynności projektowania, wzoru czy modelu, jak i samej realizacji projektu (zob. Cieślikowa, 2001; Głutkowska-Polniak, 2017, s. 7-8). Z drugiej strony, taki termin jak „wzornictwo” czy „wzornictwo przemysłowe” nie wydaje się odpowiedni na określenie projektowania interakcji między odbiorcami a wytworami filmowymi, muzycznymi itd., co równolegle bierze pod uwagę teoretyk dizajnu Donald Norman (niezależnie od innych prób przekładu tego terminu w kontekście jego prac [Norman, 2015]).
} 
Natomiast „normy społeczne” definiuję roboczo przede wszystkim w oparciu o Stanfordzka Encyklopedię Filozofii (Bicchieri i Muldoon, 2011): są to zwyczajowe zasady regulujące zachowanie jednostek i grup w danym społeczeństwie. Podmiot, jeśli ma działać normatywnie, musi mieć możliwość (fizyczną, wolicjonalną) zachowania niezgodnego z normą. Do norm społecznych zaliczam (co najmniej) większość norm moralnych. W tym kontekście praktyka normatywna to działanie podejmowane z uwagi na jakąś wartość rozumianą jako korzyść lub szkoda (służące jej realizacji lub też uniknięciu), realizowane w ramach przyjętej normy społecznej, szeroko rozumianej. Praktyki normatywne traktuję jako praktyki kulturowe analizowane z perspektywy ekologii poznawczej, bez wdawania się $\mathrm{w}$ rozstrzyganie natury norm ani tego, jak powinno się je uzasadniać.

\section{Ekologia rzeczy}

Wspomniana psychologia Gibsonowska często powołuje się na koncepcję opisującą relacje poznawcze organizmu z otoczeniem: koncepcję afordancji. Dla Gibsona afordancje to - ogólnie mówiąc - możliwości działania. Są one właściwościami relacyjnymi ustrukturyzowanego otoczenia, prowokującymi dany organizm do określonego działania (zachowania) niewymagającego namysłu. A więc krzesło podsuwa nam możliwość siedzenia, podobnie jak kamień o odpowiednim kształcie (jeśli chcemy usiąść w plenerze), a z drugiej strony krzesło może też podsuwać możliwość wybicia nim okna, gdy zachodzi taka potrzeba; jednak już to samo krzesło nie zachęci psa do siedzenia na nim, za to pomoże mu dostać się na stół po upatrzony smakołyk. Postrzegany świat (dany ekosystem) jest ustrukturyzowany nie w ogóle, lecz względem danego podmiotu. Istotne tutaj twierdzenie Gibsona głosi, że struktury naszego otoczenia są dla podmiotu znaczące, nieobojętne pod względem wartości, a wręcz obfitujące $w$ nie; otoczenie dostarcza podmiotowi afordancji dla jego pożytku lub szkody (Gibson, 1979, s. 127-143).

Koncepcja Gibsona wiąże się z pewnymi kontrowersjami, niejasnościami i niedostatkami. Do kontrowersji należy stanowisko antyreprezentacjonistyczne i hipoteza postrzegania bezpośredniego; niejasności dotyczą odniesień do społeczeństwa i kultury: postulat tego badacza dotyczący konieczności uwzględnienia wymiaru społecznego afordancji jest znikomy i rozmyty. Psychologia Gibsonowska, dość silnie zakorzeniona w biologii, nasuwa następujące wnioski: afordancja jest binarna, to znaczy istnieje albo nie istnieje; wydaje się też dość sztywna, jako coś do odkrywania, ale nie do modyfikacji; relacja afordancyjna ogranicza się do diady podmiot-obiekt; podmiot wydaje się pasywny i osamotniony, praktycznie jest tylko obserwatorem. 
Mimo wszystko koncepcja ta wpłynęła, i do tej pory wpływa, na sporą i różnorodną grupę badaczy oraz wartościowe badania (Dotov i in., 2012). W kontekście problemowym tej pracy należy zwrócić uwagę na uwzględnienie relacji między afordancjami a intencjonalnością $w$ badaniach nad percepcją znaczących elementów otoczenia (Heft, 1989), a także na wyniki nowszych badań nad rolą kontekstu społecznego w postrzeganiu afordancji podzielanych w trakcie wspólnych działań, począwszy od wczesnych form „współpracy” poznawczej rodzica z małym dzieckiem (np. Richardson i in., 2007; Ferri i in., 2011; Constancini i Sinigaglia, 2012; Joanna Rączaszek-Leonardi i in., 2013). Tym samym też poszerza się zakres afordancji: zwraca się uwagę na afordancje cielesne oraz społeczne (oba rodzaje są ze sobą powiązane), w których znaczącą rolę gra morfologia ciała, gesty, mimika, a także relacje między ciałem a kontekstem (przedmioty, miejsce, inni ludzie).

Należy tutaj wspomnieć także o dwóch zakresach badań nad afordancjami, które w pewnej mierze odnoszą się również do zastosowania tej koncepcji w dizajnie (do którego wprowadzę w następnej części). Mam tutaj na myśli $\mathrm{z}$ jednej strony afordancje $\mathrm{w}$ robotyce (np. Rome $\mathrm{i}$ in., 2006), z drugiej afordancje kulturowe (zob. Ramstead i in., 2016). W tym ostatnim obszarze na uwagę zasługują między innymi analizy Alana Costalla nad osadzeniem tych afordancji $\mathrm{w}$ ich kontekście, traktowanych jako powszechnie uzgodnione znaczenia użytkowe danych rzeczy - ujmowanych w ramach pewnych „konstelacji” innych obiektów, ludzi oraz podzielanych praktyk (Costall, 2012).

\section{Interakcje pod kontrolą}

Za równoległą względem Gibsonowskiej historię zastosowania koncepcji afordancji odpowiadają specjaliści od dizajnu. Tutaj - szeroko rozumianego, gdyż dotyczącego wzornictwa przemysłowego, projektowania interakcji człowiek-komputer, tworzenia filmów czy muzyki popularnej itd. W obszar badań nad tymi dziedzinami pojęcie afordancji wprowadził kognitywista i teoretyk dizajnu, Donald Norman. Odnosi je do postrzeganych i rzeczywistych własności rzeczy decydujących o tym, jak owa rzecz może zostać użyta (Norman, 1988/2013, s. 9). Według Joanny McGrenere i Wayne’a Ho najważniejsza różnica między Gibsonem a Normanem polega na tym, że dla pierwszego afordancje sprowadzają się do możliwości działania, a dla drugiego - do możliwości działania i jednocześnie do sposobu ich dostarczania lub uwidaczniania danemu podmiotowi (McGrenere i Ho, 2000, s. 181). Ogólnie mówiąc, Gibson analizuje afordancje zastane (niezależne od historii aktywności podmiotu), natomiast Norman - możliwości projektowania i ulepszania nowych afordancji (związanych z wiedzą i doświadczeniem podmiotu) (por. Gibson, 1979 i Norman, 1988/2013). Teoretyk dizajnu rozróżnia afordancje rzeczywiste oraz (tylko) postrzegane, pozostające czymś w rodzaju postrzeganego pozoru możliwości działania (1999, s. 38-42). Natomiast najistotniejszą kwestią 
z późniejszego okresu jego badań wydaje się znaczne docenienie roli emocji, również nieświadomych, w naszych interakcjach z otoczeniem. Norman - odwołując się do badań nad emocjami - podkreśla ich znaczenie dla myślenia, podejmowania decyzji, oceny. Jego zdaniem obecnie nie może być mowy o projektowaniu artefaktów bez uwzględniania aspektu emocjonalnego (2015).

Wreszcie istotnym wkładem teorii dizajnu w badania nad afordancjami są analizy dotyczące ich struktury i kontekstu, a także opracowanie systemu projektowania opartego na afordancjach. William Gaver opisał cztery przypadki jawności i realności afordancji, wyróżniając afordancje jawne (np. widoczna afordancja drzwi), fałszywe (atrapa klamki u drzwi), ukryte (klamka ukryta w dekoracjach drzwi), a także poprawne odrzucenie możliwości działania (gdy brak afordancji oraz percepcyjnej informacji). Ponadto badacz ten przeanalizował afordancje dla złożonych działań, opisując afordancje sekwencyjne oraz zagnieżdżone (w pierwszym przypadku każde kolejne działanie ujawnia kolejną afordancję - np. naciśnięcie klamki pozwala uchylić drzwi - natomiast $\mathrm{w}$ drugim afordancje są zgrupowane $\mathrm{w}$ pewnej większej strukturze, na przykład w całości wejścia do domu, wliczając widoczną wnękę drzwiową, schodki, same drzwi, zamek lub dzwonek, klamkę). Gaver zwraca uwagę na jawność afordancji artefaktu: danego obiektu łatwo jest użyć, gdy jego afordancje zgodne są z jego przeznaczeniem, w przeciwnym razie podsuwa nam możliwości innych działań niż te, do których został zaprojektowany. Badacz ten pokazuje również, że projektowanie interakcji człowiek-artefakt to także projektowanie interakcji społecznych - a te z kolei mają też ważny wpływ na procesy projektowania (Gaver, 1991; Gaver, 1996).

Projektowanie świadomie wykorzystujące afordancje doczekało się już pewnego upowszechnienia. Jonathan Maier i Georges Fadel pokazują, jak ważne jest $\mathrm{w}$ toku projektowania danego artefaktu nie tylko uzyskiwanie i optymalizacja pożądanych afordancji pozytywnych, ale także wyeliminowanie lub minimalizacja niechcianych afordancji negatywnych, które mogą ujawnić się mimo naszej woli, jak to bywa w projektowaniu nastawionym wyłącznie na funkcjonalność (na przykład projektując drabinę, nie wystarczy skoncentrować się na przydaniu jej optymalnej powierzchni pod stopy, stabilności lub łatwości składania, lecz powinno się także dołożyć starań, by przewidzieć i usunąć pewne wady, jak zbyt ostre krawędzie czy duże ryzyko zatrzaśnięcia sobie palców przy składaniu). Maier i Fadel, określając afordancję jako to, co jeden system umożliwia innemu systemowi, wprowadzają kategorię afordancji artefakt-artefakt (mamy z nią do czynienia choćby w przypadku dwóch kół zębatych) (Maier i Fadel, 2007; 2009, s. 23; Maier, 2015).

Przedstawiłem różnice między koncepcjami afordancji Gibsona i Normana wraz z wkładem ich kontynuatorów. Wszystkie te ujęcia łączy traktowanie afordancji jako pewnego rodzaju skrótu poznawczego. Dzięki niemu za znaczący wkład $\mathrm{w}$ interakcję poznawczą odpowiada ustrukturyzowane 
otoczenie, podsuwając działającemu osobnikowi obiekt w dużej mierze zdatny do użycia i odsuwając inne możliwości na plan dalszy, umożliwiając intuicyjne lub po prostu łatwe, niewymagające namysłu działanie.

\section{Jak powstają (masowe) rzeczy społeczne}

Jak sugerowałem na wstępie, artefakty projektowane i wytwarzane na szeroką skalę stają się w dużym stopniu rzeczami społecznymi. Dzieje się tak z kilku powodów: (1) Artefakty te są znane i wykorzystywane w różnorakich praktykach życiowych danej grupy ludzi. (2) Projektanci i producenci kierują określony model przedmiotu do określonej grupy użytkowników. (3) Standaryzacja tego modelu powoduje wprowadzenie określonych norm nie tylko produkcji, ale również eksploatacji. Ten ostatni wymiar społecznego charakteru rzeczy interesuje mnie tutaj najbardziej.

Zgodnie z przyjętym tu rozumieniem norm społecznych korzystanie z rzeczy społecznych uwikłane jest w codzienne praktyki normatywne. Przy czym koncentruję się tutaj na materialnym wymiarze tych praktyk, odniesionym do interakcji ucieleśnionego podmiotu i artefaktów. Ogólnie zgodne jest to z kognitywistycznymi koncepcjami poznania ucieleśnionego i osadzonego ${ }^{3}$. Sądzę, że na uwagę w tym kontekście zasługuje wpływ, jaki wywiera na realizację praktyk normatywnych fizyczna strona wykonywanych czynności, właściwości wykorzystywanego w jej toku artefaktu, lokalizacja przestrzenna, materialna struktura miejsca, umiejętności i możliwości techniczne, ale również zaangażowanie emocji w użytkowanie rzeczy oraz udział innych osób. Zgodnie z zarysowaną wyżej perspektywą ekologii poznawczej przyjmuję, że również w nasze normatywne interakcje ze światem zaangażowane są różnego rodzaju afordancje. Czyli nie tylko pewien dostępny zasób informacji do przetworzenia i zinterpretowania, lecz również „gotowe do użycia” struktury otoczenia modyfikujące naszą aktywność bez potrzeby deliberowania, a często i świadomej kontroli. Można powiedzieć: struktury godne naszego zaufania.

Literatura poświęcona zastosowaniu w badaniach nad normatywnością klasycznych i nieklasycznych teorii afordancji jest stosunkowo świeża i nadal niezbyt bogata. Ocenia się tam tezę Anthony’ego Chemero o normatywności afordancji, a także omawia możliwości społecznego ujęcia tej ich roli, w odniesieniu do intuicji filozoficznych, głównie Wittgensteina (Heras-Escribano i de Pinedo, 2016; Rietveld i Kiverstein, 2014; Lo Presti, 2016). Analizy te dotyczą afordancji w ujęciach postgibsonowskich, co omawiam $\mathrm{w}$ innej pracy

\footnotetext{
3 „Poznanie ucieleśnione” (embodied cognition) ogólnie oznacza istotny udział sfery cielesnej (zwykle nie tylko mózgu) w procesach poznawczych podmiotu. Poznanie osadzone (embedded cognition) odnosi się do faktu, że podmiot osadzony jest w określonym środowisku fizycznym, biologicznym i społecznym, co również ma poważny wpływ na jego czynności poznawcze (zob. Robbins i Aydede, 2008, s. 3-10).
} 
(Wachowski, 2018 [w druku]). Tutaj jednak skoncentrowałem się na wybranych konsekwencjach inżynierii afordancji, która dotyczy dziedziny szeroko rozumianego dizajnu.

Podczas gdy psychologowie ekologiczni wykorzystali kategorię afordancji w opisie aktywności poznawczej podmiotu w obrębie jego ekosystemu, teoretycy dizajnu pokazali, że interakcje afordancyjne można formować, modyfikować i kontrolować, a więc także - optymalizować lub neutralizować. Jednak w przypadku projektowania artefaktów na użytek masowy kluczowa jest jeszcze inna kwestia, mianowicie standaryzacja (inaczej: normalizacja) przemysłowa. Prowadzi ona do ujednolicania produktów pod ważnymi względami, a tym samym do większego sprecyzowania roli użytkownika: znormalizowaniu ulega również jego działanie, sprowadzone do określonych, zazwyczaj prostych czynności, zalecanych w dołączonych instrukcjach obsługi. Przekaz takich instrukcji jest dość jasny: będziesz wykorzystywał dany przedmiot tak, jak zalecamy - gwarantujemy ci bezpieczne, bezawaryjne i stosunkowo długotrwałe jego działanie lub możliwość rekompensaty w razie awarii, włącznie z możliwością roszczeń w przypadku uszczerbku na zdrowiu. Jednak pod warunkiem wykonania określonych działań i sprostania pewnym wymogom dotyczących miejsca użytkowania, przechowywania itd.

Standaryzowanie wiąże się z unifikacją, a więc ograniczeniem niepotrzebnej różnorodności. W przemyśle standaryzacja nie stanowi celu samego w sobie, lecz służy wdrożeniu istotnych norm wytwarzania, użytkowania oraz utylizacji. Dotyczą one kontroli jakości produkcji, bezpieczeństwa (co odnosi się do ochrony zdrowia i życia użytkowników oraz ich mienia i, szerzej, środowiska), ekonomii używania, dopasowania do lokalnego kontekstu technologicznego (włącznie ze źródłami zasilania, jeśli takie są konieczne), jak i z określonymi sposobami konserwacji, serwisowania i utylizacji, a nawet pewnej typizacji estetyki, obejmującej również użytkową rozpoznawalność (Wawak, 2017).

Wskutek standaryzacji, czyli wprowadzenia powszechnie uznawanych norm przemysłowych, określone społeczności otrzymują do swojego użytku artefakty o dokładnie przewidzianych funkcjach, sposobach użycia oraz warunkach łatwego, wydajnego i bezpiecznego użytkowania.

\section{Rzeczy społeczne i praktyki normatywne}

Realizacja codziennych praktyk normatywnych nie zachodzi ponad czy obok materialnej sfery naszej codzienności, ale w interakcji z nią. Artefakt materialny modyfikuje te praktyki, ułatwiając je lub utrudniając, albo wręcz je umożliwia lub uniemożliwia. Wykorzystywany jest jako (1) narzędzie działania, (2) infrastruktura techniczna tych działań lub jako (3) ich kontekst, związany z lokalizacją, dostępnością, zasobami informacji czy wreszcie celem działań. 
Wspomniane zakresy nierzadko wiążą się ze sobą, komplikując relację między użytkownikiem a artefaktem.

Najprostsze przykłady otaczają nas, wręcz wypełniają nasze życie zawodowe, domowe. Dobrze wykonany długopis od razu ujawnia obsługę mechanizmu wysuwania i wsuwania końcówki piszącej przed użytkownikiem, gdy ten weźmie go do ręki. Rzetelnie opracowana strona internetowa banku powinna nas skłonić do zminimalizowania kontaktów z żywym konsultantem. Sięgnijmy też po raz kolejny po z pozoru trywialny przykład drzwi, aby pokazać złożoność i zakres omawianego oddziaływania artefaktów. Klamki czy innego rodzaju uchwyty przy nich (na co często zwraca uwagę Norman), jeżeli są dobrze zaprojektowane i wykonane, nie pozostawiają wątpliwości nawet niezbyt przytomnemu użytkownikowi co do sposobu użycia, wliczając to, w którą stronę drzwi otwierają się.

Jednak samych użytkowników drzwi często się selekcjonuje, przepuszczając jedynie wybranych. Można posłużyć się $\mathrm{w}$ tym celu stosownym napisem lub znakiem graficznym, licząc na dobrą wolę czytających lub sugestywność informacji grożących sankcjami. Można jednak nie opierać się na zaufaniu, lecz na technice: przez wyposażenie wybranych drzwi w klucze (które jednak giną, bywają zapominane, kradzione lub nawet kopiowane), bądź też przez zamontowanie zabezpieczenia takiego jak otwieranie za pomocą wpisywanego kodu, mechanizmu będącego częścią systemu domofonu (także z kamerą) lub też systemu biometrycznego, reagującego na głos lub wykorzystującego czytnik linii papilarnych bądź też wzory naczyń krwionośnych siatkówki oka.

$\mathrm{Z}$ drugiej strony, sama lokalizacja drzwi (lub bramy) w dużej mierze decyduje o rodzaju ich użytkowników oraz funkcji. Drzwi frontowe sklepu, instytucji czy nawet dużego domu, którymi powinni wchodzić klienci, petenci czy goście, z reguły umieszczone są po „oficjalnej” stronie budynku, zwykle bardziej atrakcyjnej wizualnie, przy ulicy z chodnikiem lub dogodnym dojazdem lub nawet parkingiem dla samochodów osobowych. Natomiast wejście dla pracowników, dostawców czy domowników w porze oddawania się przydomowym obowiązkom mieści się na tak zwanych tyłach budynku, w miejscu, gdzie ułatwiono dostęp autom dostawczym oraz składowanie czy transport towarów i narzędzi. Pominąwszy dodatkowe wsparcie w postaci stosownych tablic informacyjnych (nie zawsze dostatecznie widocznych, nie zawsze obecnych), wszystkie te czynniki związane $\mathrm{z}$ usytuowaniem wejścia czy wjazdu do danego obiektu same z siebie odpowiednio nakierowują zainteresowanych ${ }^{4}$.

\footnotetext{
${ }^{4}$ Wliczając w to również złodziei. Są oni specyficznymi użytkownikami artefaktów, wykorzystującymi dizajn niejako à rebours, co szczególnie interesująco przedstawia się w przypadku kieszonkowców, nastawionych na ręczną manipulację oraz zarządzanie uwagą (zob. np. Wachowski i Bogucki, 2017).
} 
Analogiczne mechanizmy działają $\mathrm{w}$ przypadku artefaktów źle zaprojektowanych (w tym: ustrukturyzowanych przestrzeni źle zorganizowanych) - co też od razu nasuwa na myśl często opisywane przez Normana przykłady „psychopatologii” rzeczy codziennych (2013, s. 1-36): począwszy od szarpania się z nieintuicyjnie otwieranymi drzwiami, które może skończyć się uszkodzeniem przedmiotu lub użytkownika, po niebezpieczne skutki korzystania z dezorientującej, bo fatalnie zaprojektowanej, karty do głosowania.

Ostatni przykład może prowadzić do pytania o materialne usytuowanie praktyk moralnych. W odpowiedzi należy wskazać na ten sam typ mechanizmów. $\mathrm{W}$ powtarzanym już $\mathrm{w}$ literaturze przykładzie $\mathrm{z}$ mitologii (zob. Afeltowicz, 2012, s. 226) Odyseusz, aby skutecznie zabezpieczyć się przed zgubnym wpływem syreniego śpiewu (który, swoją drogą, jakże silne musiał mieć afordancje), prosi swoich towarzyszy o przywiązanie go do masztu na okręcie i w ten sposób uniemożliwia sobie rzucenie się do morza, gdyż rozsądnie nie ufa sile własnej woli. Nawet szczególnie silny „kręgosłup moralny” nie może mierzyć się z mechanizmami percepcji i emocji. A że Odyseusz wykazał się przy tym egoizmem, śmierć jego towarzyszy w morskich odmętach dowodzi użyteczności jego wynalazku. Oczywiście nietrudno o inne przykłady, takie jak idea średniowiecznego pasa cnoty, ale też współczesne rodzicielskie blokady na komputerze dziecka, filtrujące jego dostęp do Internetu.

Jak widzimy, nie wszystko tutaj jest afordancją. Pozbawienie kogoś fizycznej możliwości ruchu nie stanowi afordancji; podobnie jest z uzmysławianiem sobie sposobu użycia rzeczy w zgodzie z jakąś lokalną konwencją kulturową. Afordancje podsuwają nam możliwości działania, a nie informację czy drogę do wyszukania czy przypomnienia sobie o takich możliwościach. A jednak rozgraniczanie tego nie zawsze jest łatwe, o czym przekonuje zamieszanie pojęciowe i dyskusje na ten temat (Norman, 1999, s. 38-42; McGrenere i Ho, 2000, s. 184-185). Czynnikiem, który łączy wszystkie przypadki, kiedy to artefakt mniej lub bardziej znacząco modyfikuje praktykę normatywną, jest ograniczenie. Dotyczy ono zarówno naszego pola percepcyjnego, jak i zakresu działań, w tym fizycznych. Nakierowywanie ludzkiej percepcji i działania na pożądaną praktykę zawsze wiąże się z odsuwaniem na plan dalszy lub eliminacją innych opcji, z manipulacją naszymi możliwościami wyboru. Warto przypomnieć sobie tutaj zasadę projektowania, zgodnie z którą projektowanie artefaktów obejmuje optymalizację afordancji (czy też właściwości obiektu) korzystnych oraz eliminację szkodliwych.

Ów wybór zostaje dokonany nie na etapie użytkowania, lecz projektowania. Projektant, pamiętając o swoich zobowiązaniach związanych ze standaryzacją oraz wobec producenta, projektuje dany artefakt i jednocześnie nasze działania związane z jego użyciem, jedynie uzupełniając to o źródła informacji dołączane do produktu. Projektując zabawkę dla dzieci, z zasady pozbawia małego 
użytkownika możliwości szkodliwego dla niego użycia przedmiotu, a jednocześnie eksponuje możliwości wykorzystania potencjalnie atrakcyjnego. W przypadku dorosłych trudno oczekiwać tak doskonałego produktu; chodzi raczej o utrudnienie wyboru, o odsunięcie niepożądanych możliwości na daleki plan, do którego nie dotrzemy, jeśli będziemy posługiwać się przedmiotem zgodnie $\mathrm{z}$ jego przeznaczeniem - i tu właśnie dochodzi do głosu instrukcja obsługi oraz wiedza potoczna dotycząca artefaktu, jeśli jest powszechnie używany. Projektowanie może uwzględniać również kwestie pokoleniowe, począwszy od umieszczania niebezpiecznych elementów wyposażenia czy obsługi urządzeń na odpowiedniej wysokości, aż po pewne „sprytne” rozwiązania jak to opisane przez Marcina Wichę: pojemnik z witaminami z systemem otwierania zabezpieczonym przed małymi dziećmi staje się skuteczną alternatywą dla ostrzegających ulotek, zamykanych szafek, umieszczania takich substancji z dala od maluchów oraz ciągłego pamiętania o tym, by być ostrożnym (Wicha, 2015).

Oczywiście nietrudno wyobrazić sobie jakiś przedmiot domowej roboty, który wykorzystuje podobnie przemyślny mechanizm, a który nie został opatentowany i powielony. Poważna różnica leży gdzie indziej. Jeśli używamy w toku codziennych czynności jakiegoś przedmiotu o innym lub niesprecyzowanym przeznaczeniu, ponosimy za to sami w całości odpowiedzialność, niekiedy też odpowiedzialność za innych partycypujących w tych czynnościach, którzy nam zaufali. Chodzi o dużą skalę możliwych działań, począwszy od prostych prac domowych - od których amatorskie majsterkowanie jest zwykle nieodłączne a skończywszy na pracach na większą skalę typu dobudowa domu lub naprawa pojazdu. Gdy natomiast w toku jakiejś przedsięwziętej czynności sięgamy po artefakt specjalnie do tego celu wytworzony, nasza odpowiedzialność jest ograniczona - w zasadzie sprowadzona do wierności instrukcji obsługi przedmiotu oraz poprawnego korzystania z sieci elektrycznej, wodnej itd. - bo obdarzamy zaufaniem pośrednio producenta, a bezpośrednio sprzedawcę rzeczy, z którym związaliśmy się umową zakupu. Główną odpowiedzialność ponosi tutaj wytwórca, określając ją $\mathrm{w}$ granicach wyznaczonych $\mathrm{z}$ jednej strony przez standaryzację, z drugiej - przez dany autorski projekt, wykonane testy oraz kontrolę produkcji poszczególnych egzemplarzy.

\section{Rola emocji}

Rzeczy społeczne nie tylko są w jakieś mierze dopasowane do naszych ciał i umiejętności fizycznych, do innych artefaktów z naszego otoczenia, czy też do naszych zwyczajów kulturowych, a przy tym wszystkim - dostosowane do przyjętych lokalnie zasad bezpieczeństwa. Artefakty angażują też naszą emocjonalność na różnych jej poziomach, na co już zwróciłem uwagę, prezentując pokrótce wkład Normana w teorię dizajnu. 
Przyjrzyjmy się bliżej tej kwestii. Oddziaływanie „czystego” (co jest również względne) piękna przejrzystej użytkowości stanowi tylko pewien zakres wpływu artefaktu na nasze emocje. Pierwszym etapem - od razu o najszerszym oddziaływaniu społecznym - jest oddziaływanie reklamy. Marketing od dawna nie ogranicza się do podkreślania jakości wyrobu ani uświadamiania zapotrzebowania na coś, ale próbuje kreować nowe potrzeby, chętnie odwołując się przy tym do ekspresji młodości, prorodzinnych sentymentów czy elementów kulturowych. Mogłoby się wydawać, że zjawiskiem bazującym na potrzebie wyłącznie estetycznej zmiany jest moda; jednak i tutaj działania marketingowe odwołują się często do praktyczności i - zwłaszcza - innowacji. Tak zwana nowoczesność to tutaj często atut sam w sobie. Wreszcie etapem najbardziej oddalonym od fizycznych właściwości artefaktu, a głęboko poruszającym emocjonalność klienta, jest promocja samej marki (Jones, 2012).

Aspekt mody towarzyszy również dalszemu użytkowaniu zakupionego przedmiotu, przy czym etap stymulacji pozytywnej jest stosunkowo krótki; im bardziej rzecz staje się niemodna, tym silniejsze uczucie wstydu lub irytacji może budzić. Oczywiście moda jako taka raczej wyklucza się niż pokrywa z normami; jednak sama tendencja do podążania za modą może być traktowana jako efekt normatywnego wpływu społecznego.

Czynnikiem zwykle konkurującym, ale niekiedy też wspierającym modę i marketing, jest sentyment. Projektant może odwołać się do naszej wrażliwości na kontekst kulturowy. Jednak ostatecznie „warstwa” sentymentalna nakładana jest przez samego użytkownika w odniesieniu do jego własnych doświadczeń i wspomnień. Do najdziwniejszych z perspektywy klasycznego dizajnu należą przypadki, kiedy to z satysfakcją użytkujemy wyraźnie niedoskonały przedmiot codziennego użytku, na przykład jakiś imbryk do herbaty, zamiast zaopatrzyć się w lepszy, a to z tego powodu, że darzymy go wielkim sentymentem (Norman, 2005, s. 3-24).

Natomiast świadome wykorzystywanie przez projektanta emocji w projektowaniu interakcji użytkownik-artefakt wydaje się kwestią niejednoznaczną etycznie. W niektórych przypadkach projektanci mogą zbliżać się do czegoś w rodzaju szantażu emocjonalnego, gdy manipulują odwołaniami do tożsamości narodowej, religii czy zdrowia. Łagodniej już działa „poprawianie” wyglądu tanich rzeczy w taki sposób, na przykład przez nadawanie jakiemuś urządzeniu wyglądu znacznie bardziej profesjonalnego, czyli wykorzystywanie fałszywych afordancji w postaci dysproporcji i atrap. Można też do tego wykorzystać skeumorfizm: imitowanie tworzyw, kształtów czy innych aspektów w innym przedmiocie, na przykład drewna w tapecie czy wypukłych przycisków manualnych na wirtualnym pulpicie komputera. 
Wicha (2015) przytacza opinie wybitnych projektantów, którzy powtarzają, że dizajn powinien być uczciwy. Autor ten powątpiewa w uniwersalność owego założenia. Szczerość projektanta, przejawiająca się $\mathrm{w}$ przejrzystym prezentowaniu funkcji i jakości artefaktu, dobrze sprawdza się w salonie, kuchni czy w obiektach sportowych. Ale czy aby na pewno potrzebujemy analogicznej szczerości artefaktów w takim miejscu jak szpital? Czy rzeczywiście na każdym kroku chcemy pokazywać pacjentom i osobom postronnym jaskrawą prawdę, że otacza ich tylko przeznaczony do takich a nie innych celów sprzęt medyczny, którego wygląd nie powinien odwoływać się do życia poza murami szpitalnymi? Z całym prawdopodobieństwem $\mathrm{w}$ takim miejscu odegra ważną rolę wykorzystanie afordancji fałszywych oraz ukrytych. Ludzie, stając się pacjentami, nie przestają być ludźmi, nie tracą sfery emocjonalnej. Z tych zresztą względów pierwsze samochody przypominały dorożki, a pierwsze urządzenia elektryczne - meble .

\section{Obiekty użytku publicznego}

Do artefaktów angażowanych w praktyki normatywne należą też większe ustrukturyzowane przestrzenie, jak zabudowa miejska czy wyposażanie miejsc publicznych (wątek ten pojawił się już podczas opisywania roli lokalizacji drzwi). Obiekty te zazwyczaj oddziaływują silnie na większą grupę ludzi w danym czasie. Zarówno struktura ulic, uporządkowanie otoczenia mieszkalnego czy instytucjonalnego, jak i rozwiązania architektoniczne danych budynków wymuszają na nas bardzo określone zachowania związane $\mathrm{z}$ przemieszczaniem się, zachowaniem $\mathrm{w}$ sklepach czy poczekalniach, wypoczynkiem czynnym lub biernym itd.

Trudno tu oczywiście podtrzymywać wątek prostego, kontrolowanego projektu otoczenia. Praktycznie każda lokalna, otaczająca nas przestrzeń, szczególnie miejska, to efekt nałożenia się różnych warstw projektów, niekiedy już szczątkowych, oraz prób dopasowania ich o różnym stopniu skuteczności. Skupmy się na przestrzeni miejskiej. Jej współtwórcy zwykle nadają jej pewne funkcje $\mathrm{w}$ ramach określonych miejsc $\mathrm{w}$ tej przestrzeni, adresowanych do mniej lub bardziej konkretnych grup społecznych. I to właśnie one dostarczają dobrych przykładów na różnicę między projektowaniem skoncentrowanym wyłącznie na funkcji a projektowaniem opartym na afordancjach. Niejednokrotnie mamy tutaj do czynienia ze specjalnie zaprojektowanymi przestrzeniami spacerowymi, po których prawie nikt nie chce spacerować, miejscami osiedlowych spotkań sąsiedzkich, do których nie zagląda żaden sąsiad, czy też poprzecinanymi ścieżkami ozdobnymi rabatami roślinnymi, które ciągle są dewastowane. Nawet jeżeli te miejsca doskonale spełniają swoją

5 "Koń wziął dzień wolnego, jutro na pewno znów będzie” - jak humorystycznie opisał wrażenie z takiego „ostrożnościowego” projektu Wicha (2015). 
funkcję, to problem leży często po stronie afordancji, negatywnych lub ukrytych. Otoczenie miejsca spacerowego lub też jedyne dostępne drogi dojazdowe mogą zniechęcać sanitarnie lub estetycznie. Docelowe miejsca spotkań sąsiedzkich mogą być pozbawione aspektów wyraźnie zachęcających do takich celów, natomiast posiadać wiele afordancji ściągających tam miejscowych narkomanów z uwagi na dyskretność lokalizacji i pewne oddalenie od klatek schodowych. A zlokalizowanie hodowli roślin ozdobnych na linii jedynej drogi do szkoły i poprzecinanie jej obszaru prostokątnie skręcającymi ścieżkami powoduje, że przechodzące często tamtędy grupy dzieci skracają sobie drogę na ostrych zakrętach, a nierzadko też niefrasobliwie zrywają fragmenty roślinności do celów zabawy. Jednym z najpopularniejszych problemów przestrzeni miejskich jest problem lawek: jak je zaprojektować i gdzie rozmieścić, by służyły do przysiadania na nich spacerowiczów czy okolicznych mieszkańców, ale nie zachęcały do spania lub libacji alkoholowych.

Towarzyszą temu wyzwania, które w projektowaniu wiążą się z afordancjami artefakt-artefakt oraz zwierzę-artefakt. Zdatna do użytku przestrzeń miejska powinna być nie tylko skoncentrowana (bezpośrednio) na człowieku, ale również optymalizowana pod kątem spójności technologicznej oraz relacji ze środowiskiem naturalnym. Koła rowerów i aut wymagają innych nawierzchni i rozwiązań technicznych niż obute ludzkie stopy. Jeszcze mniej kompromisowym „partnerem” dialogu jest spływająca woda, kruszący się mur czy grzyby. A być może najmniej przewidzianym czynnikiem są zwierzęta (nie domowe) w kontakcie ze sztucznym otoczeniem (zob. np. de Oliveira i Neto, 2015).

Ponieważ projektowanie to nie tylko zarządzanie afordancjami i ogólnie właściwościami artefaktu, również w miejscach publicznych nieodzowne bywają konwencjonalne informacje, instrukcje obsługi, byle były krótkie, zrozumiałe i odpowiednio wyeksponowane. Należy jednak brać pod uwagę sytuacje, kiedy nie zdają one egzaminu. To sytuacje wypadków, awarii, korków na ulicy czy komunikatów o zagrożeniu. Ludzie w panice, pojedynczo lub w grupie, często reagują już tylko na afordancje. Napierający na drzwi tłum nie wdaje się $\mathrm{w}$ analizowanie sposobów otwierania ich, po prostu na nie napiera ${ }^{6}$.

Do urządzeń $\mathrm{w}$ miejscach publicznych, których projektantom zarzuca się zdumiewającą arogancję, należą niektóre polskie automaty do sprzedaży biletów. Z cokolwiek dowcipnej analizy takiego automatu, której dokonał Wicha, wynika, że zaprojektowano go dla istot dość niskiego wzrostu i obdarzonych długimi rękoma ze szponiastymi palcami, które nadają się do mozolnego wydobywania wyślizgującej się reszty pieniędzy i biletu z bardzo nisko położonego pojemnika z osłoną (Wicha, 2012).

${ }^{6}$ Zakres wad projektowania nie tylko drzwi i konsekwencje tego dla bezpieczeństwa publicznego zob. Norman, 1988/2013. 
Projektowa nonszalancja dotyczy nadal niektórych formularzy w urzędach, które z trudem można wypełnić, a niekiedy nawet zrozumieć. Ranga tego problemu niebywale urasta, gdy mamy do czynienia ze wspomnianymi już, tak nieudolnie zaprojektowanymi i przez to wprowadzającymi niejednego wyborcę w błąd kartami do głosowania lub urządzeniami do głosowania (zob. np. Wicha, 2015; Tognazzini, 2001), że może to nawet przesądzić o jego wynikach.

\section{Rola innych}

Czynnikiem, który względnie niedawno został odpowiednio doceniony w badaniach nad poznaniem, jest wpływ obecności innych ludzi na naszą percepcję. Przy czym badacze podejmują również trud analizowania początków, czyli interakcji matek z niemowlętami, która owocuje rozwojem podzielanej między nimi intencjonalności. Dzięki temu dzieci nabywają między innymi zdolności spostrzegania oraz stwarzania interaktywnych afordancji społecznych. Niemowlęta uczą się reagowania na przedmiot $\mathrm{w}$ intencjonalnej współpracy z matką (Rączaszek-Leonardi i in., 2012, s. 210-221).

Badania z udziałem dorosłych pokazały między innymi, jak zmienia się nasze postrzeganie rzeczy - jako narzędzi czy też w ogóle przedmiotów podatnych na nasze działanie - nie tylko w zależności od tego, czy znajdują się one w obrębie naszej przestrzeni peripersonalnej (na przykład w zasięgu naszego uchwytu ręką), czy poza, ale również w zależności od tego, czy w pobliżu znajdują się inne osoby, czy dany przedmiot jest w ich zasięgu, czy z nami współpracują, czy podzielają z nami intencjonalność itd. (np. Richardson i in., 2007; Costantini i Sinigaglia, 2012, s. 431-459). Tym samym afordancje przedmiotów nie są afordancjami w ogóle, sztywno i na stałe określonymi ich właściwościami, lecz zmieniają się w zależności od kontekstu interpersonalnego, włącznie z lokalizacją rzeczy względem danych osób. Spostrzeżenia te dość dobrze wpisują się w „konstelacyjne” wyjaśnianie statusu afordancji artefaktów, proponowane przez przytaczanego wcześniej Costalla. W jego świetle "Rzeczy najlepiej rozumieć [...] nie jako ustalone i niezależne od ludzi, ale zmienne, a nawet powstające $\mathrm{w}$ wyniku bieżących praktyk, na które z kolei te przedmioty oddziałują" (Costall, 2012, s. 303).

Zastanówmy się nad następującym przypadkiem: oto spostrzegamy starszą i schorowaną osobę, która wyraźnie ma trudność ze wspięciem się po stromym wejściu do tramwaju. Jakie możliwe reakcje obecnych tam obserwatorów możemy sobie wyobrazić? Jedni wykazują odruch rzucania się do pomocy, czy to w pojedynkę, czy we współpracy z inną obecną tam osobą. Inni odsuwają się na „bezpieczną” odległość, z której poczucie zobowiązania maleje wraz z odległością fizyczną i tym samym możliwością szybkiego udzielenia pomocy. Jeszcze inni - rozglądają się w poszukiwaniu „bardziej chętnych”, w ostate- 
czności skłonni, choć z oporami, do pomocy. Prawdopodobnie znajdzie się również grupa takich obserwatorów, którzy pozostają całkowicie obojętni, nie czując potrzeby przemieszczenia się lub pozorowania stanu nieuwagi. Jak widzimy, trudno w tym - pozornie prostym - przypadku zidentyfikować jakieś jednoznaczne, zakorzenione w naszej kulturze reakcje (i afordancje kulturowe) przypisane widokowi osoby potrzebującej pomocy. W świetle poczynionych wcześniej uwag nie wystarczy nam tutaj prosta konstatacja: taki widok skłania do ustosunkowania się wobec pewnej powinności lub zwyczaju kulturowego (ustosunkowania się pozytywnego lub negatywnego). Znaczenia nabiera bowiem zarówno nasza fizyczna lokalizacja czy dostępność dla potrzebującego pomocy, obecność i usytuowanie osób trzecich, jak również to, jak mogą nas one postrzegać i oceniać.

\section{Podsumowanie}

Celem niniejszego studium było omówienie społecznego charakteru artefaktów powszechnego użytku. Charakter ten wynika nie tylko z faktu, że dane społeczności podzielają pewne przedmioty czy też wykorzystują je podczas wspólnych działań, oraz że pewne artefakty produkowane są na użytek masowy, lecz również z tego, iż wprowadzenie tych rzeczy do powszechnego użytku wiąże się $z$ jednoczesnym wprowadzeniem znormalizowanych sposobów ich eksploatacji, a także z przejęciem części odpowiedzialności za skutki tej eksploatacji przez projektantów, producentów i dystrybutorów. Z tego też powodu, opisując praktyki normatywne, $w$ które angażowane są rzeczy społeczne, nie oddzielam wśród nich praktyk moralnych od innych, wszystkie one bowiem muszą w podobny sposób mierzyć się z „oporem” szeroko rozumianej fizyczności elementów danego otoczenia, w którym (a nie ponad którym czy niezależnie od którego) są realizowane. Wytwarzanie artefaktów na szeroką skalę daje ich wytwórcom swoistą władzę, gdyż podejmują za nas wiele decyzji co do sposobu użytkowania przedmiotu, i jednocześnie obejmuje ich znaczną odpowiedzialnością. Przestrzeń tak pojętego dizajnu w założeniu stanowić ma kontrolowaną przestrzeń systematycznej optymalizacji życia społecznego i jednostkowego. Co oczywiście nie znaczy, że wolnej od błędów i ryzyka.

Umiejscowienie tych rozważań w ramach ekologii poznawczej nie oznacza od razu pozyskania zadowalających sposobów analizy. Na pewno nie wystarczy samo zastosowanie koncepcji afordancji. Zidentyfikowanie określonych afordancji $\mathrm{w}$ przestrzeni interakcji człowieka $\mathrm{z}$ otoczeniem nie oznacza wyjaśnienia zjawisk, natomiast służy naświetleniu „węzłów” interakcji poznawczych w ludzkim ekosystemie kulturowym, co można dalej wykorzystywać badawczo. 
Niniejsze studium częściowo stanowi rozwinięcie moich analiz nad usytuowaniem normatywności w ludzkich ekosystemach kulturowych, $\mathrm{z}$ naciskiem na rolę artefaktów (Wachowski, 2018 [w druku]). Poza tym dostarczać ma ono wskazówek do dalszych badań i konceptualizacji, zwłaszcza z wykorzystaniem dorobku teoretycznego dizajnu, który moim zdaniem nie został do tej pory właściwie doceniony przez interdyscyplinarne nauki nad poznaniem.

Dziękuję dwojgu anonimowych recenzentów pierwszej wersji tego tekstu za cenne uwagi, których część wykorzystam też w dalszych badaniach.

Pracę zrealizowano $\mathrm{w}$ ramach grantu Narodowego Centrum Nauki PRELUDIUM 8 (decyzja nr DEC-2014/15/N/HS1/03994).

\section{Bibliografia}

Afeltowicz, Ł. (2012). Modele, artefakty, kolektywy. Toruń: Wydawnictwo UMK.

Bicchieri, C., Muldoon, R. (2011). Social Norms. In Stanford Encyclopedia of Philosophy, https://plato.stanford.edu (12.01.2017).

Chemero, A. (2009). Radical Embodied Cognitive Science. Cambridge: MIT Press.

Cieślikowa, A. (2001). Design czy dizajn? Kwartalnik 2+3D.

Costall, A. (2012). Afordancje kanoniczne w kontekście. tłum. K. Bielecka. Avant 3/2, 296304.

Costantini, M. Corrado, S. (2012). Grasping affordance. In A. Seemann (Ed.), Joint attention: New developments (pp. 431-459). Cambridge: MIT Press.

Dotov, D. Nie, L., de Wit, M. (2012). Zrozumieć afordancje. tłum. D. Lubiszewski, N. Strehlau. Avant, 3(2012)2, 282-295.

Ferri, F., Campione, G. C., Volta, R. D., Gianelli, C., Gentilucci, M.. (2011). Social Requests and Social Affordances. PLOS ONE, 6(1), e15855, 1-9.

Gaver, W. (1991). Technology affordances. Proceedings of the ACM CHI, 91, 79-81

Gibson, J. (1979/2014). The Ecological Approach to Visual Perception. New York: Psychology Press.

Głutkowska-Polniak, A. (2017). Dizajn w kontekście estetyki. Jego poczatki, przeobrażenia i konotacje. Katowice: Uniwersytet Śląski.

Heras-Escribano, M., de Pinedo, M. (2016). Are affordances normative? Phenomenology and the Cognitive Sciences, 15(4), 565-589.

Hutchins, E. (1995). Cognition in the wild. MIT Press, Cambridge.

Hutchins, E. (2010). Cognitive Ecology. Topics in Cognitive Science, 2 (2010) 4, 707-712. 
Hutchins, E. (2014). The cultural ecosystem of human cognition. Philosophical Psychology, 27(2014) 1, 34-49.

Lo Presti, P. (2016). An ecological approach to normativity. Adaptive Behavior, 24(1), 3 17.

Maier, J. R. A., Fadel, G. M. (2009). Affordance based design: a relational theory for design. Research in Engineering, 20/ 1, 13-27.

McGrenere, J., Ho, W. (2000). Affordances: Clarifying and Evolving a Concept. The Proceedings of Graphics Interface, Montreal, 179-186.

Norman, D. (1988/2013). The Psychology of Everyday Things. New York: Basic Books.

Norman, D. (1994). Things That Make Us Smart. New Jork: Basic Books.

Norman, D. (1999). Affordance, conventions, and design. Interactions, 6(3), 38-42.

Norman, D. (2015/2004). Wzornictwo i emocje. Dlaczego kochamy lub nienawidzimy rzeczy powszechnie. Tłum. D. Skalska-Stefańska. Warszawa: Arkady.

Rączaszek-Leonardi, J., Nomikou, I., Rohlfing, K.. (2013). Young children's dialogical actions: The beginnings of purposeful intersubjectivity. IEEE Transactions on Autonomous Mental Development, 5(3), 210-221.

Richardson, M. J., Marsh, K. L., Baron, R. M. (2007). Judging and actualizing intrapersonal and interpersonal affordances. Journal of Experimental Psychology: Human Perception and Performance, 33/4, 845-859.

Rietveld, E., Kiverstein, J. (2014). A rich landscape of affordances. Ecological Psychology, 26(4), 325-352.

Robbins, P., Aydede, M. (2008). A Short Primer on Situated Cognition. In P. Robbins, M. Aydede (Eds.), The Cambridge Handbook of Situated Cognition. Cambridge: Cambridge University Press.

Wachowski, W., Bogucki, K. (2017). Designed for Pickpockets. The Ecological Approach to Perception in (A)social World. In Ch. Limbeck-Lilienau, F. Stadler (Eds.), The Philosophy of Perception and Observation, Contributions of the Austrian Wittgenstein Society (pp. 271-273). Kirchberg am Wechsel, Vol. XXV, 2017.

Wachowski, W. (2018). [w druku] Normatywność usytuowana. Ujęcie ekologiczne. Studia Philosophiae Christianae, (1). DOI: 10.21697/spch.2018.54.1.16

Wawak, S. (2017). Standaryzacja. W: Encyklopedia Zarządzania. Źródło https://mfiles.pl/pl/index.php/Standaryzacja.

Wicha, M. (2015). Jak przestałem kochać design (How I stopped love design). Kraków: Wydawnictwo Karakter. E-book. 
How social things work. Cognition, normativity, and design for the masses

\begin{abstract}
One can speak about the social involvement of things not only in the language of posthumanism. People design and produce artifacts. The social character of the latter comes not only from everyday use or from use in cooperation between people but also from the system of various social norms in context of which we use these things. I discuss the issue of situating social artifacts in normative practices from the perspective of cognitive ecology and, at the same time, design theory.
\end{abstract}

Keywords: cognitive ecology; artifact; social norm; affordance; dizajn 